REVIEW ARTICLE

\title{
An insight into black cutworm (Agrotis ipsilon): A glimpse on globally important crop pest
}

\author{
Christopher Rodingpuia*, H. Lalthanzara \\ Department of Life Sciences, Pachhunga University College, Mizoram University, Aizawl 796001, India
}

\begin{abstract}
Many agricultural pests create problems for farmers leading to production loss. Since agriculture plays an important role in the economy of a nation, controlling and management of such pests is of great importance. Cutworms are notorious agricultural pests infesting a wide variety of crops leading to production loss. Cutworms are distributed worldwide and many species of cutworms have also been reported feeding on all kinds of crops. Agrotis ipsilon is one of the most common cutworm species prevailing in different continents. Understanding the biology and management of these pests will be of great use for farmers. In this article, brief information on cutworms; specifically $A$. ipsilon species is highlighted. A brief description of host, migration, control and management of $A$. ipsilon are also highlighted.
\end{abstract}

Keywords: Caterpillars, infestation, host, parasite, economy, control-management.

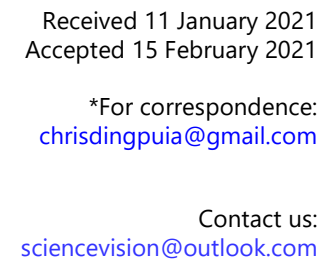

Received 11 January 2021

*For correspondence:

Contact us: sciencevision@outlook.com

\section{Introduction}

Cutworms are caterpillars belonging to the order Lepidoptera and family Noctuidae; a large family of moth. $^{1-4}$ Cutworms got their names from their feeding habit of "cutting-off"' a seedling at ground level by chewing through the stem. Most noctuid species are cutworms. However, there are also species under the family Noctuidae that have the same feeding habit as cutworms but are not considered as cutworms. ${ }^{1-4}$ Some of the common cutworms are army cutworm, black cutworm, bristly cutworm, bronzed cutworm, claybacked cutworm, dingy cutworm, pale western cutworm, sandhill cutworm and variegated cutworm. ${ }^{5-8}$ They may be grey, brown, green or yellow. ${ }^{1-8}$ Cutworms are having longitudinal stripes and the length of the larval form may extend up to 1 inch $(2.5 \mathrm{~cm}) .{ }^{4}$ There are variations within the genera and may differ depending on the region where they are found. ${ }^{1-4}$ Most common cutworm species are Agrotis ipsilon and $A$. segetum. ${ }^{1-8}$

The life cycle of cutworm consists of egg, pupa, larva, pupa and adult. ${ }^{9-14}$ Newly laid eggs are about $0.5 \mathrm{~mm}$ in diameter and are cream coloured and turn into reddish-yellow to blackish colour on hatching. ${ }^{9-}$ ${ }^{14} \mathrm{~A}$ female cutworm may lay around 2000 eggs and are usually laid singly or in groups on the roots, stems and on the low growing vegetation of the host plant and eggs usually hatch within 10-28 days. The larva is $4-5 \mathrm{~cm}$ long, pale, yellowish-green and possesses a blackish head. ${ }^{9-14}$ Newly hatched larvae 

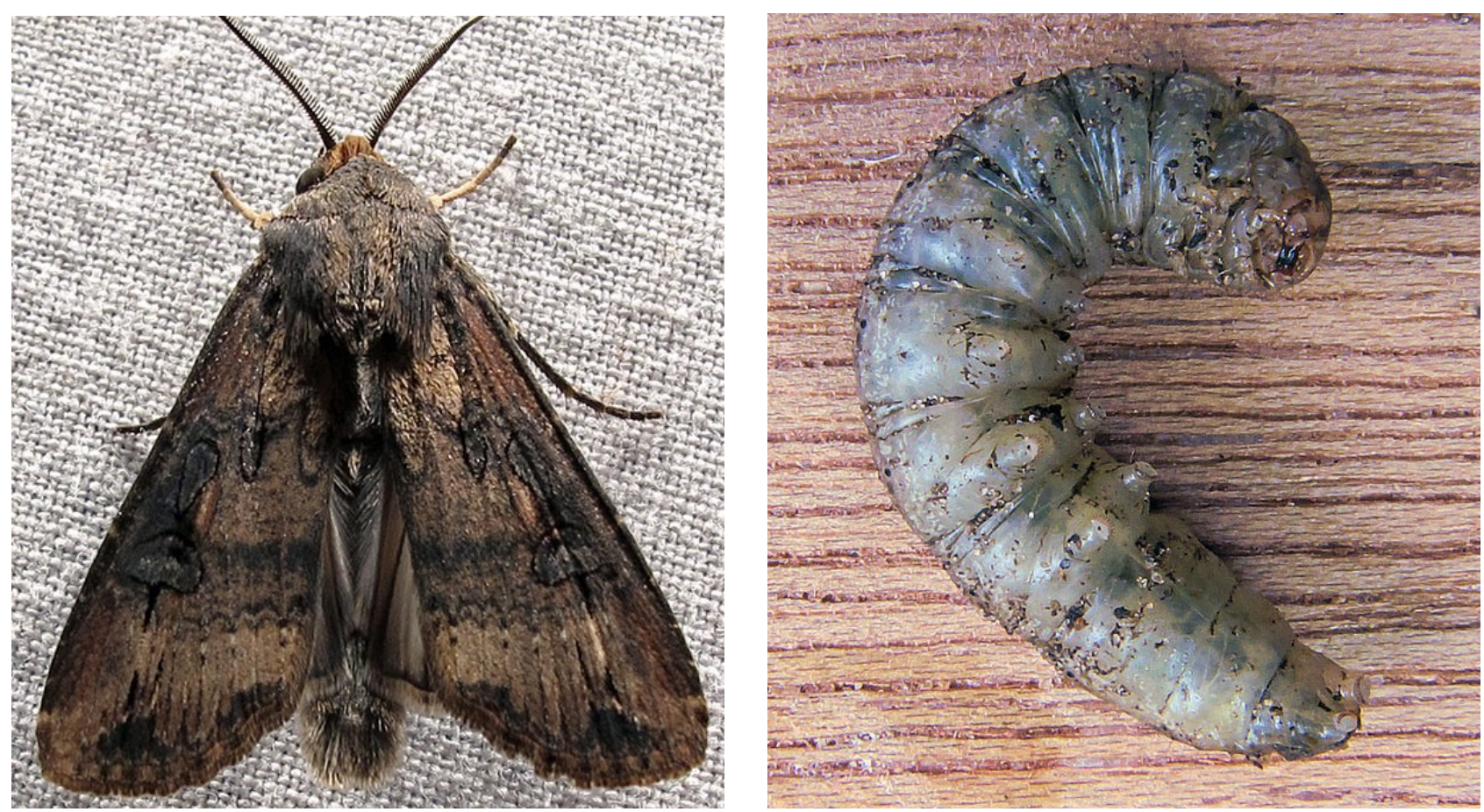

Figure 1 | Male lack cutworm (Agrotis ipsilon) (left; Jacy Lucier, commons.m.wikimedia.org CC-BY SA 4.0). The larva (right; Rasbak, commons.wikimedia.org CC-BY SA 3.0).

usually feed on the leaves and then feed on the stem of the host plant in the later stage of larva and pupa is having two dark stripes around the abdomen, which are smooth and reddish-brown in colour. $^{9-14}$ During their late-stage they appear to be blackish in colour just before the moth emerges. The adult moth has greyish-brown forewings with black lines and kidney-shaped markings along the side margins. ${ }^{9-14}$ The hindwings in adult moth are whitish with brownish margins and veins and the entire cutworm life cycle is completed within 6 weeks under warm condition and are having one generation per year. ${ }^{9-14}$

Cutworms are notorious agricultural and garden pests. As noctuids they are nocturnal and active at night. ${ }^{9-14}$ The larvae of cutworms are the most damaging and active feeders of the voracious leaf bud and stem and could potentially destroy entire plants if not controlled. ${ }^{9-14}$ However, some species are subterranean and root feeders. Variegated cutworm (Peridroma saucia) can defoliate an entire garden and fields in a matter of days. ${ }^{9-14}$ During daytime, adult moths hide at the bases of the host plant and grassy weed. Neonate larvae can be found under leaf littering on the ground in the dry land field while in wetland habitat they are found on the host plant, above the water surface. ${ }^{9-14}$ Cutworms are known to attack cultivated plants belonging to at least 15 families viz., Poaceae, Malvaceae, Brassicaceae, Solanaceae, Euphorbiaceae,
Asteraceae, Theaceae, Fabaceae, Rubiaceae, Cucurbitaceae, Rutaceace, Rosaceae, Apiaceae, Fabaceae, Lamiaceae. ${ }^{23-58}$ Common host plants are rice, maize, cotton, potato, tomato, cotton, pea, okra, cabbage, cauliflower, bell pepper, mustard, coffee. ${ }^{9-}$ 14

Cutworms are distributed at various places throughout the countries of the continents of Africa, Asia, Europe, North America, Oceania and South America. ${ }^{23-58}$

\section{Biology and Description Black Cutworm}

\section{Systematic classification}

Domain: Eukaryota

Kingdom: Animalia

Phylum: Arthropoda

Class: Insecta

Order: Lepidoptera

Superfamily: Noctuoidea

Family: Noctuidae

Genus: Agrotis

Species: A. ipsilon

\section{Description}

Black Cutworm (A. ipsilon) common name - dark sword-grass, greasy cutworm, floodplain cutworm, 
or ipsilon dark are noctucid that are found to be distributed throughout the globe and possess serious threats to agricultural crops nearly in all varieties of vegetables and many important grains. ${ }^{16}$

${ }^{21}$ When fully grown, lavae can measure up to $40 \mathrm{~mm}$ in length. ${ }^{16-21}$ The larvae of $A$. ipsilon are black-pale grey with a greasy appearing texture possessing convex granules on the abdominal segments. When touched, the larvae have the tendency to roll becoming thread-like in appearance.

\section{Life cycle}

Like other cutworms, $A$. ipsilon life cycle consists of egg, larva, pupa and adult. ${ }^{16-21}$ The larval form of $A$. ipsilon is the most active and feed on the vegetative parts of the host plants, mainly the stem and roots. Small irregular holes are found on the leaves of the host plant and the later instar may cut the stems below the soil surface resulting in plant death. ${ }^{5-8}$ Wilting of the host plant may be observed due to partial cutting. Larvae are destructive, as single larvae may cut one plant and quickly moves to other plant. Such feeding habit results in disproportional damage to crops and may damage the entire stands of the crops such as cotton and maize. ${ }^{5-8}$

A. ipsilon are known to cause the most economic damage of all the cutworm species. In India, $A$. ipsilon is a notorious agricultural pest infesting Zea mays (maize) and other important agricultural crops throughout the year. ${ }^{22}$ They are active during the month of October to March in the Indian plains and during summer in the mountainous regions. $A$. ipsilon is a serious insect pest of maize in Himachal Pradesh causing 23.92 percent of production loss of this crop. ${ }^{22}$ Since maize is a Kharif crop mostly grown during the rainfed season, $A$. ipsilon cause serious damage during the early stage of growth (up to 4 leaf growth). ${ }^{22}$

\section{Host}

A. ipsilon feed on a wide variety of crops, seedling plants are most seriously damaged. ${ }^{1-4}$ They also feed on grass and weeds. Some of the main host plants of A. ipsilon are Triticum (wheat), Zea mays (maize), Solanum tuberosum (potato), Solanum lycopersicum (tomato), Musa (banana), Gossypium (cotton), Cucumis sativus (cucumber), Brassica nigra (black mustard), Abelmoschus esculentus (okra), Saccharum officinarum (Sugarcane), Brassica oleracea (cabbages, cauliflower), Camellia sinensis (tea), Coffea (coffee), Daucus carota (carrot), Mentha (mints), Pisum sativum (pea), Nicotiana tabacum (tobacco), Papaver somniferum (opium poppy), Phaseolus (beans), Raphanus sativus (radish), Sorghum bicolo (sorghum), Trifolium (clovers), Prunus domestica (plum). ${ }^{23-58}$

\section{Distribution}

A. ipsilon is widely distributed across the globe and is known to damage crops in North, Central, and South America, Asia, Europe, Oceania, Middle-East and Africa. ${ }^{23-58} A$. ipsilon is a serious agricultural pests in the tropical and subtropical regions of the world, causing significant loss in crop production in countries such as Chile, Brazil, Egypt, India, Myanmar, Poland, Spain, and USA. ${ }^{1-14}$

\section{Migration}

A. ipsilon is reported to be a seasonal migratory moth that travels North during the spring season and South during the fall season to escape the harsh hot and cold weather during the summer and winter season. ${ }^{16-21}$ A sudden increase in the population of $A$. ipsilon, often in large numbers and seasonal disappearances in countries like India, Egypt, Sulawesi and the Middle East was reported proving that this pest is a migratory moth. In many parts of the world, it has been suggested that migration is the main source for the black cutworm moth population ovipositing on early spring crops. ${ }^{23-58}$ Migration is influenced by both thermoperiod and photoperiod. ${ }^{16-21}$ Migration period also determines the reproductive behaviour of the moth. Before the moth migrates South during fall, the reproductive system of both males and females is shut down, thus preventing copulation during winter. During spring and early summer, before migrating north, females release sex pheromones soon after eclosion. The production and release of sex pheromone by females and pheromone responsiveness in males are dependent on the juvenile hormone $(\mathrm{JH})$ and pheromone biosynthesis activating neuropeptide (BPAN). ${ }^{16-21}$

\section{Control and Management}

Cutworms are one of the most challenging agricultural pests when it comes to control and management due to their peculiar feeding habit and mode of infesting their host plant. Several management techniques and practices were reported to be successful in controlling cutworms such as host-plant resistance, chemical control, and biological control. ${ }^{23-58}$

In general, it was reported that cutworms can be managed by avoiding the plantation of crops in areas that are reported to have cutworm outbreaks. Regular ploughing of fields, especially during autumn has also been reported to be successful in controlling the pest. Traps also serve as a useful tool in controlling A. ipsilon population. ${ }^{23-58}$

Host-plant resistance is an effective method in controlling and managing the pest. This is achieved by the transfer of three genes cowpea trypsin 
inhibitor (CpTi), barley trypsin inhibitor (Bti-me), and Bacillus thuringiensis cry $1 \mathrm{Ac}$ gene $(\mathrm{Bt})$ to the host plant of $A$. ipsilon making the host plant resistant to $A$. ipsilon as these genes code for the production of different insecticidal toxin. ${ }^{23-58}$

Synthetic insecticides such as clothianidine, common alum, aluminium potassium sulphate (solid), and aluminium oxide (liquid) were reported to be effective against $A$. ipsilon larva and egg. A recent study also shows that chlorantraniliprole, a novel anthranilic diamide insecticide is also effective for controlling $A$. ipsilon. In India, diazinon $20 \mathrm{EC}$, quinalphos $25 \mathrm{EC}$, chlorpyrifos $20 \mathrm{EC}$, fenitrothion 50 $\mathrm{EC}$, deltamethrin $2.8 \mathrm{EC}$ and malathion $5 \%$ activity was tested against $A$. ipsilon on potato among which chlorpyrifos $20 \mathrm{EC}$ was found to be the most effective in controlling A. ipsilon. ${ }^{23-58}$

Natural insecticides such as neem products, methanol extract from Melia azedarach fruits, extract of Bassia muricata, extract of Tephrosia nubica, leaf extracts of Lantana, Parthenium, Hypis and Ipomoea carne, were found to be very effective in controlling A. ipsilon. Although chemical control is very effective with a high success rate for controlling and managing $A$. ipsilon, precautionary measures should be taken while using pesticides as other species of animals are also affected. ${ }^{23-58}$

Recent studies show that entomopathogenic nematodes, Steinernema spp. and Heterorhabditis spp. were an effective biological control against $A$. ipsilon. ${ }^{1-4}$ Studies were also conducted in endemic nematodes in India for potential biological control against $A$. ipsilon. A parasite Hexamermis arvalis, an entomopathogenic nematode, was reported in the U.S. ${ }^{16-21}$ This parasite is reported to infect $60 \%$ of cutworm larvae and killing the host. ${ }^{23-58}$ Cutworms have several enemies such as wasps, beetles, ants specifically Lasius neoniger species which feed on $A$. ipsilon larvae and eggs may also be useful for controlling the pest in agricultural fields and gardens. Volatile chemical substances that are extracted from Populus nigra leaves are used for attracting $A$. ipsilon which can be used for setting up traps. ${ }^{23-58}$

\section{References}

1. Smit, B. (1964). Insects in Southern Africa. How to Control Them. A Handbook for Students, Health Officers, Gardeners, Farmers. Annecke, D. P., \& Moran, V. C. (1982). Insects and mites of cultivated plants in South Africa. Butterworth.

2. Henaish, M., \& Elmetwaly, N. (2020). Identification and taxonomic notes of Spodoptera species (Lepidoptera: Noctuidae) known to occur in Egypt. Egyptian Academic Journal of Biological Sciences. A, Entomology, 13(2), 161-175.

3. Sorensen, K. A., Mohankumar, S., \& Thangaraj, S.
R. (2016). Physical, mechanical and cultural control of vegetable insects. In Integrated Pest Management of Tropical Vegetable Crops. Springer, Dordrecht, pp. 131-148.

4. Hein, G. L., Campbell, J. B., Danielson, S. D., \& Kalisch, J. A. (2006). Management of the Army Cutworm and Pale Western Cutworm. University of Nebraska, Lincoln, USA.

5. Fishel, F., Bailey, W. C., Boyd, M. L., Johnson, W. G., O'Day, M. H., Sweets, L., \& Wiebold, W. J. (2009). Introduction to Crop Scouting. Extension publications (MU).

6. Calvin, D. D., Van Duyn, J. W., Steffey, K. L., Rice, M. E., All, J., Andow, D. A., \& Gray, M. E. (1999). European corn borer. Handbook of Corn Insects. Entomological Society of America, Lanham, MD, pp. 78-82.

7. Peairs, F. B. (2006). Caterpillars in small grains. Insect Series. Crops; no. 5.577.

8. Hunt, D. J., Luc, M., \& Manzanilla-López, R. H. (2005). 2 Identification, Morphology and Biology. Plant parasitic nematodes in subtropical and tropical agriculture, 11.

9. Elwell, H., \& Maas, A. (1995). Natural Pest and Disease Control. Natural Farming Network.

10. Hill, D. S. (1983). Agricultural Insect Pests of the Tropics and their Control. CUP Archive

11. Stoll, G. PAN Germany Online Information Service for Non-chemical Pest Management OISAT. In International Symposium on Biopesticides for Developing Countries (p. 161). Bib. Orton IICA/ CATIE.

12. Siddig, S. A. (1987). A proposed pest management program including neem treatments for combating potato pests in the Sudan. In Natural Pesticides from the Neem Tree, pp. 449-459.

13. Varela, A. M., \& Seif, A. (2004). A guide to IPM and hygiene standards in okra production in Kenya.

14. Fernandes, F. L., Diniz, J. F., Silva, P. R., \& Mosca, E. (2013). Damage of Agrotis ipsilon (Lepidoptera: Noctuidae) on Coffea arabica in Brazil. Revista Colombiana de Entomología, 39(1), 49-50.

15. Showers, W. B. (1997). Migratory ecology of the black cutworm. Annual Review of Entomology, 42(1), 393-425.

16. Duportets, L., Gadenne, C., Dufour, M. C., \& Couillaud, F. (1998). The pheromone biosynthesis activating neuropeptide (PBAN) of the black cutworm moth, Agrotis ipsilon: immunohistochemistry, 
characterization and bioassay of its peptide sequence. Insect Biochemistry and Molecular Biology, 28(8), 591-599.

17. Capinera, J. L. (2006). Common name: Black cutworm, scientific name: Agrotis ipsilon (Hufnagel) (Insecta: Lepidoptera: Noctuidae). Entomology and Nematology of University of Florida. Tersedia online di http:// entnemdept. ufl. edu/creatu res/veg/black_cutworm. htm\# da ma [diakses pada 10 April 2017].

18. Picimbon, Jean-Francois. Juvenile hormone stimulates pheromonotropic brain factor release in the female black vutworm, Agrotis ipsilon. Journal of Insect Physiology, 41, 377-382.

19. Gray, M. E. (2011). Relevance of traditional integrated pest management (IPM) strategies for commercial corn producers in a transgenic agroecosystem: a bygone era? Journal of Agricultural and Food Chemistry, 59(11), 5852-5858.

20. López, R., \& Potter, D. A. (2000). Ant predation on eggs and larvae of the black cutworm (Lepidoptera: Noctuidae) and Japanese beetle (Coleoptera: Scarabaeidae) in turfgrass. Environmental Entomology, 29(1), 116-125.

21. Sidhu, K. S., Sharma, S. D., \& Sharma, P. K. (2019). Occurrence and biodiversity of cutworms (Agrotis spp.) in maize agro-ecosystem in submountainous hill region of North-Western Himalayas, India.

22. Abdel-Gawaad, A. A., \& El-Shazli, A. Y. (1971). Studies on the common cutworm Agrotis ypsilon Rott: I. Life cycle and habits. Zeitschrift für Angewandte Entomologie, 68(1-4), 409-412.

23. Abdinbekova, A. A., \& Akhmedov, R. M. (1981). Features of the photoperiodic adaptation of some species of owlet moths (Noctuidae, Agrotinae) in Azerbaijan. Trudy Vsesoyuznogo Entomologicheskogo Obshchestva, 63, 166-168.

24. Salehi, H., Seddighi, Z., Kravchenko, A. N., \& Sticklen, M. B. (2005). Expression of the cry1Ac in Arizona Common'Common Bermudagrass via Agrobacterium-mediated transformation and control of black cutworm. Journal of the American Society for Horticultural Science, 130(4), 619-623.

25. Cui, J., Xia, J., \& Ma, Y. (2002). Resistance of transgenic Cry1Ac and Cry1Ac+ CpTI cottons to black cutworm [Agrotis ipsilon]. Journal of Hubei Agricultural College, 22(2), 3-7.

26. Cui, J., \& Xia, J. (1997). The effect of Bt transgenic cotton on the feeding function of major predators. China Cottons, 24(2).

27. Luo, M., Yang, T., Ding, Y., Duan, Z., \& Han, J.
(1999). On the resistance of Bt and CpTI dually transgenic tobacco to larvae of oriental tobacco budworm and black cutworm. Acta Phytophylacica Sinica, 26(3), 225-229.

28. Liu, T. S., \& Yang, Y. Z. (1987). Life history and field occurrence of Agrotis ipsilon in Taichung (Noctuidae: Lepidoptera). Plant Protection Bulletin, Taiwan, 29(3), 255-262.

29. MISHRA, V. K. (2020). Insect pests of cumin and their management. In Management of Insect Pests in Vegetable Crops: Concepts and Approaches, p. 73.

30. Frank, S. D., \& Shrewsbury, P. M. (2004). Effect of conservation strips on the abundance and distribution of natural enemies and predation of Agrotis ipsilon (Lepidoptera: Noctuidae) on golf course fairways. Environmental Entomology, 33(6), $1662-1672$

31. Story, R. N., \& Keaster, A. J. (1982). Development and evaluation of a larval sampling technique for the black cutworm (Lepidoptera: Noctuidae). Journal of Economic Entomology, 75(4), 604-610.

32. Story, R. N., \& Keaster, A. J. (1983). Modified larval bait trap for sampling black cutworm (Lepidoptera: Noctuidae) populations in field corn. Journal of Economic Entomology, 76(3), 662666.

33. Andersch, W., \& Schwarz, M. (2003). Clothianidin seed treatment (Poncho®)-the new technology for control of corn rootworms and secondary pests in US-corn production. Pflanzenschutz Nachrichtenbayer, 56, 147-172.

34. Talpur, M. A., Qureshi, K. H., \& Nizamani, I. A. (2002). Effectiveness of different insecticides against greasy cutworm, Agrotis ipsilon (Hufn.) on cauliflower crop. Pakistan Journal of Applied Sciences, 2(2), 216-218.

35. Mishra, D. N. (2002). Chemical control of cut worm, Agrotis ipsilon on potato in mid hill conditions. Annals of Plant Protection Sciences, 10(1), 151-153.

36. Viji, C. P., \& Bhagat, R. M. (2001). Bioefficacy of some plant products, synthetic insecticides and entomopathogenic fungi against black cutworm, Agrotis ipsilon larvae on maize. Indian Journal of Entomology, 63(1), 26-32.

37. Viji, C. P., \& Bhagat, R. M. (2001). Studies on life history of black cutworm, Agrotis ipsilon Hufn. on maize. Shashpa, 8(1), 33-39.

38. Schmidt, G. H., Ahmed, A. A., \& Breuer, M. (1997). Effect of Melia azedarach extract on larval development and reproduction parameters of 
Spodoptera littoralis (Boisd.) and Agrotis ipsilon (Hufn.) (lep. noctuidae). Anzeiger für Schädlingskunde, Pflanzenschutz, Umweltschut, 70 (1), 4-12.

39. Ramesh, C. (2004). Status of medicinal plants with respect to infestation of insect pests in and around Chitrakoot, District-Satna (MP). Flora and Fauna (Jhansi), 10(2), 88-92.

40. El-Sayed, N. H., Mogahed, M. I., Haron, A. A., \& Mabry, T. J. (1998). Flavonoids and other constituents from Bassia muricata and their insecticidal activities. Revista Latinoamericana de Quimica, 26(3), 81-85.

41. Shalaby, F. F., El-Hafez, A. A., El-Khayat, E. F., \& El-Sharkawy, M. A. A. (2000). Effect of shifting the rearing host on fecundity, emergence and sex-ratio of Trichogramma evanescens Westwood and Trichogrammatoidea bactrae Nagaraja. Egyptian Journal of Biological Pest Control, 10(1/2), 1-14.

42. Nassar, M. M. (2000). Assessment of two natural marine toxins (Microcystis aeruginosa and Parasicyonis actinostoloides) for the control of some medical and agriculture insects with reference to the action on mice. Journal of the Egyptian Society of Parasitology, 30(2), 631-641.

43. Thakur, A. S., Vaishampayan, S. M., \& Abhishek, S. (1997). Evaluation of some soil insecticides against cutworm, Agrotis ipsilon (Hufnagel) in sunflower. Crop Research (Hisar), 14(3), 477-480.

44. Thakur, S. S. (1997). Rumex nepalensis-a biopesticide against black cutworm, Agrotis ypsilon (Rottenburg). Insect Environment, 3(2), 34-35.

45. Hussaini, S. S., Rabindra, R. J., \& Nagesh, M. (2003). Current status of research on entomopathogenic nematodes in India: Workshop on the Entomopathogenic Nematodes in India held on 22 and 23rd January, 2003. In Current status of research on Entomopathogenic Nematodes in India: Workshop on the Entomopathogenic Nematodes in India. Project Directorate of Biological Control, Indian Council of Agricultural Research.

46. Hussaini, S. S., Rabindra, R. J., \& Nagesh, M. (2003). Current status of research on entomopathogenic nematodes in India: Workshop on the Entomopathogenic Nematodes in India held on 22 and 23rd January, 2003. In Current status of research on entomopathogenic nematodes in India: Workshop on the Entomopathogenic Nematodes in India. Project Directorate of Biological Control, Indian Council of Agricultural Research.

47. Hussaini, S. S., Singh, S. P., \& Shakeela, V. (2003). Variable efficacy of different formulations of entomopathogenic nematodes against black cutworm Agrotis ipsilon (Hufnagel) larvae. In Biological Control of Lepidopteran Pests. Proceedings of the Symposium of B iological Control of Lepidop teran Pests (PL Tandon, CR Ballal, SK Jalali, RJ Rabindra, Eds), PDBC, Bangalore, pp. 193-198.

48. Baur, M. E., Kaya, H. K., \& Tabashnik, B. E. (1997). Efficacy of a dehydrated steinernematid nematode against black cutworm (Lepidoptera: Noctuidae) and diamondback moth (Lepidoptera: Plutellidae). Journal of Economic Entomology, 90(5), 1200-1206.

49. Shapiro, D. I., Lewis, L. C., Obrycki, J. J., \& Abbas, M. (1999). Effects of fertilizers on suppression of black cutworm (Agrotis ipsilon) damage with Steinernema carpocapsae. Journal of Nematology, 31 (4S), 690.

50. Guo, X., Yuan, G., Fan, C., Zheng, Q., \& Ma, J. (2001). Determination of chemical components of the odor with luring activity from withered black poplar leaves by gas chromatography-mass spectrometry. Journal of Henan Agricultural University, 35(1), 24-25.

51. Salama, H. S., Salem, S. A., Zaki, F. N., \& AbdelRazek, A. (1999). The use of bacillus thuringiensis to control Agrotis ypsilon and Spodoptera exigua on potato cultivations in Egypt. Archives of Phytopathology \& Plant Protection, 32(5), 429-435.

52. Carrillo, R., Cornejo, C., Neira, M., Balocchi, O., Mundaca, N., \& Cisternas, E. (2001). Larvae of noctuids associated to permanent pastures in Valdivia, Chile, during winter time. Agro Sur, 29 (1), 27-31.

53. Carillo, R., Norambuena, H., Rebolledo, R., \& Mundaca, N. (1988). Flight and seasonal abundance of four species of Noctuinae in the IX and $X$ regions, Chile: the first two years of observations. Revista Chilena de Entomología, 16, 3339.

54. Secchi, V. A. (2001). Situation of soil pests in Rio Grande do Sul: a view of rural extension. Documentos-Embrapa Soja, 172, 17-41.

55. Verma, K. S., \& Verma, A. K. (2002). Cutworm species associated with different crops in Himachal Pradesh. Insect Environment, 8(1).

56. Morris, H., \& Waterhouse, D. F. (2001). The Distribution and Importance of Arthropod Pests and Weeds of Agriculture in Myanmar (No. 435-201633715).

57. Murillo, H., Hunt, D. W., \& VanLaerhoven, S. L. (2013). First records of Chrysodeixis chalcites (Lepidoptera: Noctuidae: Plusiinae) for east- 
central Canada. The Canadian Entomologist, 145(3), 338-342.
58. Walczak, F. (2002). Beware of noctuids and other soil pests. Ochrona Roślin, 46(8), 8-10. 